http://ejournal.upi.edu/index.php/jaz/ - e-mail: jurnal.zonasi@gmail.com dan jurnal_zonasi@upi.edu

\title{
KERENTANAN BAHAYA KEBAKARAN DI KAWASAN KAMPUNG KOTA Kasus: Kawasan Balubur Tamansari Kota Bandung
}

\begin{tabular}{|c|c|}
\hline $\begin{array}{l}\text { Article History: } \\
\text { First draft received: } \\
\quad 30 \text { Januari } 2019 \\
\text { Revised: } \\
\quad 5 \text { Januari } 2019 \\
\text { Accepted: } \\
\quad 9 \text { Januari } 2019 \\
\text { Final proof received: } \\
\text { Print: } \\
\quad 10 \text { Februari } 2019 \\
\\
\text { Online } \\
\quad 11 \text { Februari } 2019\end{array}$ & 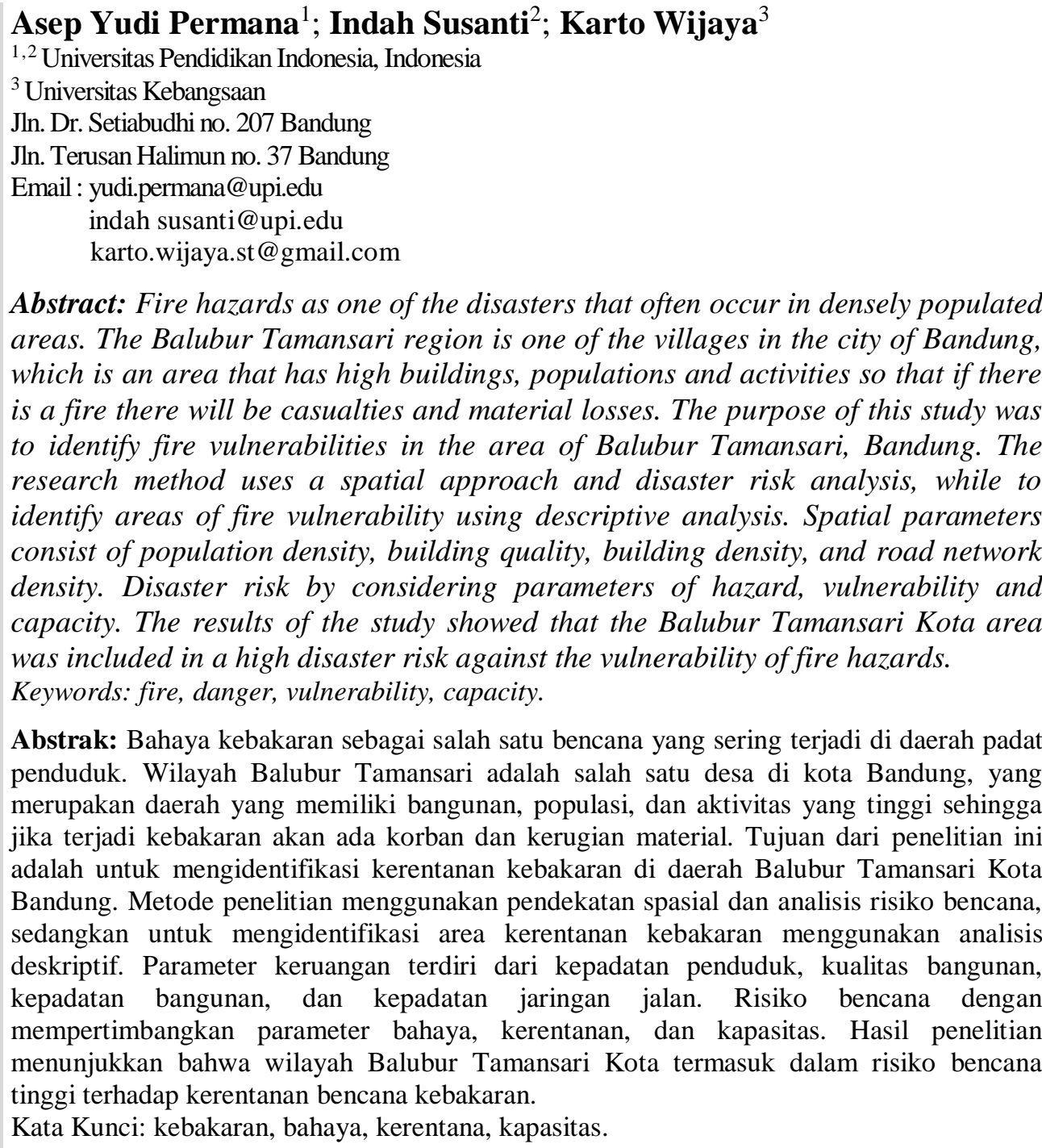 \\
\hline
\end{tabular}

\section{Pendahuluan}

Indonesia secara geografis yang terletak pada daerah khatulistiwa dengan morfologi yang beragam (Taridala, Yudono, Ramli, dan Akil, 2017), kondisi ini memiliki potensi bencana yang cukup tinggi karena adanya aktivitas pergerakan lempeng tektonik aktif (Marfai, Cahyadi, dan Anggraini, 2013). Potensi bencana meliputi bahaya utama, seperti gempa bumi dan Longsor (Permana, 2011). Letusan gunungapi, tsunami dan banjir, serta potensi bahaya ikutan, seperti wabah penyakit, kebakaran, dan konflik sosial (Taridala et al., 2017). Potensi bencana ikutan di wilayah perkotaan yang paling tinggi adalah bahaya kebakaran (Marfai et al., 2013; Nurwulandari, 2016; Taridala et al., 2017), hal ini disebabkan karena wilayah perkotaan memiliki tingkat kepadatan penduduk tinggi, kompleksitas penggunaan lahan, pemusatan aktivitas penduduk perkotaan, penggunaan material bangunan, dan adanya daerah-daerah permukiman kumuh perkotaan (Permana, 2012a; Taridala et al., 2017). 
Kota Bandung sebagai salah satu 5 (lima) kota besar di Indonesia mengalami pertumbuhan penduduk yang pesat tahun ke tahunnya. Salah satu penyumbang pertumbuhan penduduk di kota Bandung adanya migrasi mahasiswa (Permana, 2014). Kawasan Balubur Tamansari merupakan salah satu lokasi yang berada di daerah aliran Sungai Cikapundung (Permana, Sumarna, dan Wijaya, 2017; Permana dan Wijaya, 2018; Permana, Susanti, dan Wijaya, 2018). Berdasarkan perkembangannya Kawasan Balubur Tamansari ini merupakan salah satu titik perkembangan dari sejarah berdirinya Kota Bandung (Haroyoto Kunto, 1984; Haryoto Kunto, 1986). Pada awal berdiri Kawasan Balubur Tamansari ini merupakan satu kawasan tempat peristirahatan dan tempat pesiar sinyo dan none Belanda (Haryoto Kunto, 1986a; Permana, 2014). Tempat ini dikenal sebagai tempat pelesiran (Haryoto Kunto, 1986b) atau wisata di sekitar Situ Gojali (sekarang sudah berubah menjadi permukiman ekslusif di antara permukiman padat penduduk) dan dikenal dengan daerah Pelesiran (Haroyoto Kunto, 1984; Voskuil, 2007; Widjaja, 2013; Permana, 2014).

Seiring dengan perkembangan Kota Bandung (Permana, 2012b), kawasan ini menjelma menjadi kawasan padat penduduk (Widjaja, 2013; Permana, 2014). Hal ini sebagai dampak dari perkembangan angka pertumbuhan penduduk (Budihardjo, 1984) yang begitu pesat dengan perubahan komposisi dan alokasi penduduk yang drastis akibat arus urbanisasi (Budihardjo, 1997; Budihardjo, 2011; Soetomo, 2012; Permana, Soetomo, Hardiman, dan Buchori, 2013). Perkembangan jumlah penduduk Kota Bandung adalah 2.490.622 jiwa dengan tingkat kepadatan penduduk sebesar 148,47 orang/Ha atau (BPS Kota Bandung, 2017). Kondisi ini mempengaruhi keseimbangan kota yaitu tingkat kepadatan bangunan (Permana, 2012; Nurwulandari, 2016).

Kawasan Balubur Tamansari merupakan satu kesatuan yang tidak bisa terpisahkan dengan kampus Insitut Teknologi Bandung/ITB (Haryoto Kunto, 1986b; Permana dan Wijaya, 2013), karena di dalam perencanaan kampus Technische Hoogeschool (disingkat THS/ sekarang ITB) merupakan kebun Botani sebagai fasilitas kampus THS. Secara administrasi Kawasan Balubur Tamansari ini terdiri 3 RW dengan 11 RT dan mempunyai luas lahan sebesar 45 Ha (BPS Kota Bandung, 2017). Dari segi kepemilikan lahan di kawasan ini terbagi menjadi 3 kelompok kepemilikan, yaitu (1) tanah hak milik perorangan; (2) tanah milik PJKA/PT. KAI; dan (3) tanah milik negara yaitu marka Sungai Cikapundung (Permana, 2014). Penggunaan lahan pada kawasan ini 95\% digunakan sebagai lahan terbangun (Permana, 2012; (Permana, 2014), sehingga kawasan ini menjadi salah satu kawasan kumuh (slums) dan padat penduduk.

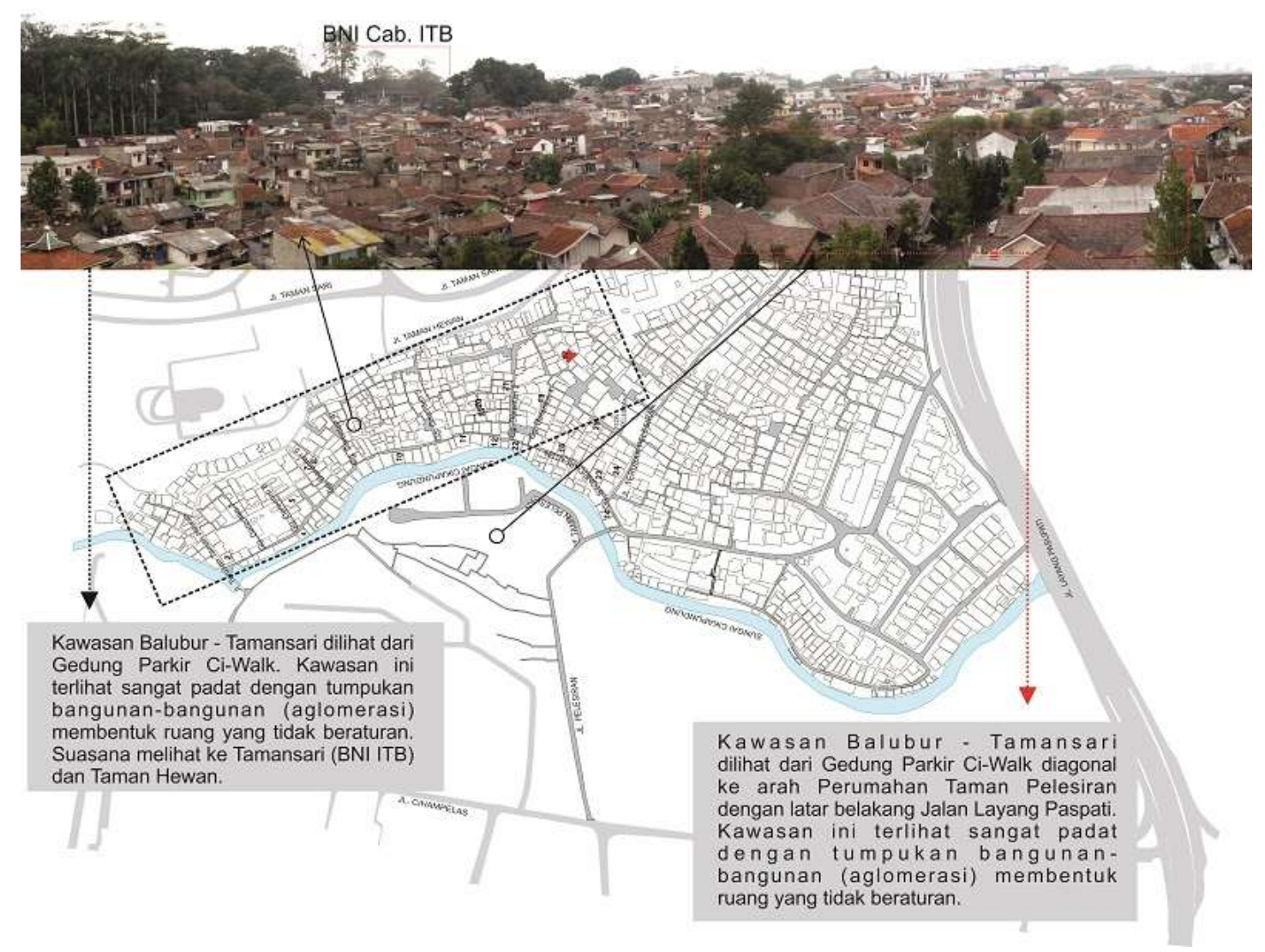

Gambar 1. Kondisi Kawasan Balubur Tamansari Kota Bandung Sumber: Modifikasi hasil survey 2013 - 2018 
Kawasan Balubur Tamansari sebagai penyangga dari kebutuhan bermukim mahasiswa untuk perguruan tinggi ternama, salah satunya adalah Insitut Teknologi Bandung sebagai perguruan tinggi tertua di Kota Bandung (Permana, 2014). Arus urbanisasi yang terjadi terutama dari para mahasiswa mengakibatkan kebutuhan akan bermukim. Arus migran mahasiswa ini memberikan dampak terhadap kondisi di Kawasan Balubur Tamansari menjadikannya sebagai salah satu kawasan padat. Penyalahgunaan daerah hijau menjadi lahan terbangun mengakibatkan berkembangnya permukiman padat untuk pemenuhan kebutuhan masyarakat. Secara historis, Kawasan Balubur Tamansari merupakan lingkungan permukiman yang tumbuh secara alami, sebagai kampung kota yang tumbuh menjadi besar secara alami tanpa menjalami proses perencanaan kota. Seiring dengan berjalannya waktu kawasan ini menjadi kampung padat, bila dilihat dari tingkat kerapatan antar bangunan yang tinggi, penggunaan lahan yang tidak teratur, dan lebar jalan/gang yang semakin menyempit(Wijaya, Permana, dan Swanto, 2017). Hal ini sebagai akibat adanya peningkatan kebutuhan masyarakat untuk tempat bermukim. Peningkatan kebutuhan masyarakat ini tidak selalu disertai dengan kepedulian akan pentingnya keamanan dan keselamatan dari ancaman bencana, salah satunya adalah bencana kebakaran (Nurwulandari, 2012; Nurwulandari, 2016). Kebakaran sebagai salah satu bencana yang seringkali terjadi di perkotaan, berdasarkan data Badan Pusat Statistik Kota Bandung tahun 2018 jumlah kejadian kebakaran selama tahun 2017 kurang lebih 198 kali kejadian dengan area kebakaran sebesar 3.316 $\mathrm{m}^{2}$ (Badan Pusat Statistik Kota Bandung, 2018).

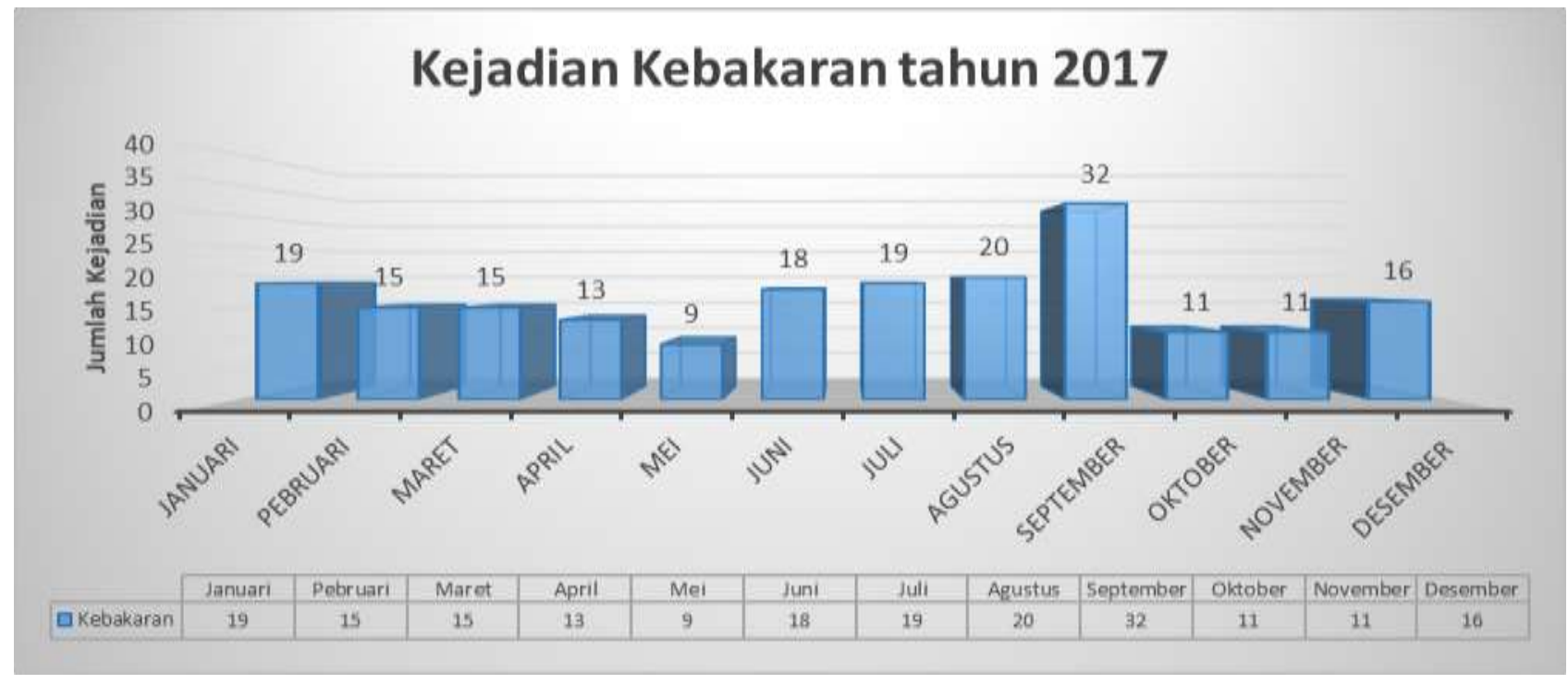

Gambar 2 Diagram Kejadian Kebakaran di Kota Bandung selama tahun 2017 Sumber: BPS Kota Bandung, 2018

Dari data diagram gambar 1 terlihat bahwa Kota Bandung merupakan salah satu kota yang rentan bahaya bencana kebakaran dengan rata-rata perbulan sebanyak 16,5 kejadian.

Kebakaran (Rahmat, Prianto, dan Sasongko, 2018) sebagai salah satu bencana yang seringkali terjadi di perkotaan, mengancam keselamatan jiwa manusia maupun harta benda jika nyala api tidak terkendali.(Januandari, Rachmawati, dan Sufianto, 2017). Kebakaran terjadi sebagai reaksi segitiga api/fire triangle yaitu reaksi dari bahan yang mudah terbakar/fuel oksigen dan panas/heat. Menurut tempatnya kebakaran dibagi menjadi 4 (empat) yaitu kebakaran permukiman, kebakaran industri, kebakaran transportasi, dan kebakaran hutan (Sukmo, Suroto, dan Wahyuni, 2016). Kebakaran kawasan permukinan biasanya terjadi di kawasan permukiman perkotaan yang padat penduduk.

Masalah yang ingin diketahui dalam penelitian ini adalah: (1) Bencana kebakaran di perkotaan tidak bisa diprediksi kapan terjadinya dan penyebabnya, yang dapat dilakukan adalah dengan persiapan dan peringatan dini. Kawasan Balubur Tamansari merupakan salah satu kawasan padat penduduk di Kota Bandung; (2) Kemampuan masyarakat dalam mitigasi bencana (Sukmo et al., 2016) diukur berdasarkan tingkat kemampuan dalam mengakses informasi tentang bahaya kebakaran di lingkungan padat penduduk, serta tata cara dalam melakukan pencegahan dan penanggunalangan bencana.

Adapun tujuan penelitian ini adalah (1) untuk mengidentifikasi kerentanan bencana dan tingkat risiko bencana dengan menggunakan variabel bahaya, kerentanan, dan kapasitas di Kawasan Balubur Tamansari Kota Bandung. (2) untuk mengidentifikasi kemampuan masyarakat dalam menghadapi bahaya kebakaran, dan tata cara dalam melakukan pencegahan dan penanggulangan bencana. 


\section{Metode Penelitian}

\subsection{Lokasi Penelitian}

Lokasi kajian terletak di kawasan Balubur Tamansari yang meliputi 3 RW dengan 11 RT.

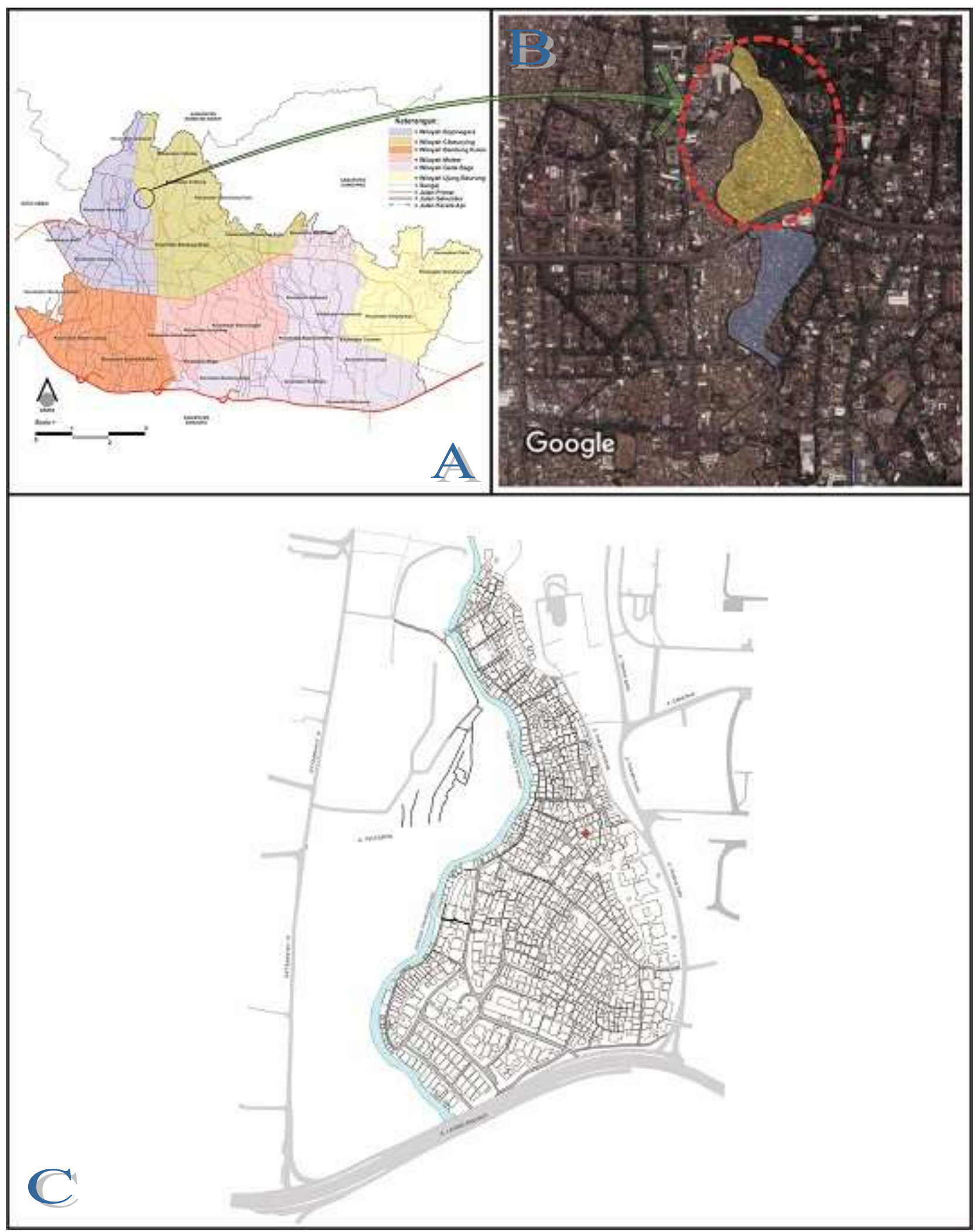

Gambar 3 A) Peta Pembagian Wilayah Kota Bandung; B) Peta Satelit Kawasan Balubur Tamansari; dan C) Peta Kawasan Balubur Tamansari Kota Bandung

Sumber: Modifikasi hasil survey, 2013-2018 


\subsection{Pendekatan Penelitian}

Pendekatan penelitian menggunakan pendekatan keruangan (Sujatmiko, 2012) dan analisis risiko bencana (Januandari et al., 2017), sedangkan untuk mengidentifikasi wilayah kerawanan kebakaran menggunakan analisis deskritif (Sujatmiko, 2012). Paramater dalam menentukan wilayah rawan kebakaran berdasarkan pada 4 variabel, yaitu: kepadatan penduduk, kualitas bangunan, kepadatan bangunan, dan tingkat kerapatan jaringan jalan. Rumus Risiko Bencana adalah:
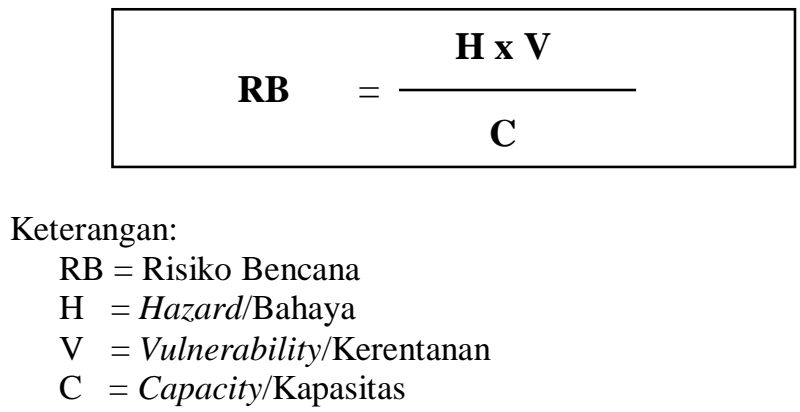

Klasifikasi wilayah rentan bencana kebakaran permukiman dibagi menjadi 3 kategori, yaitu rendah, sedang, dan tinggi seperti pada tabel 1 .

Tabel 1. Klasifikasi Wilayah Rentan Bencana

\begin{tabular}{|l|c|c|c|}
\hline \multirow{2}{*}{\multicolumn{1}{|c|}{ Parameter }} & \multicolumn{2}{c|}{ Kerentanan Kebakaran Permukiman } \\
\cline { 2 - 4 } & Rendah & Sedang & Tinggi \\
\hline Kepadatan Penduduk & $<150 \mathrm{Jiwa} / \mathrm{Ha}$ & $150-200 \mathrm{wa} / \mathrm{Ha}$ & $>200 \mathrm{Jiwa} / \mathrm{Ha}$ \\
\hline Kualitas Banguna & $<5 \%$ & $5-15 \%$ & $>15 \%$ \\
\hline Kepadatan Bangunan & $<32 \mathrm{Unit} / \mathrm{Ha}$ & $32-57 \mathrm{Unit} / \mathrm{Ha}$ & $>57 \mathrm{Unit} / \mathrm{Ha}$ \\
\hline Kerapatan jaringan jalan & $>105 \mathrm{~m} / \mathrm{Ha}$ & $75-105 \mathrm{~m} / \mathrm{Ha}$ & $<75 \mathrm{~m} / \mathrm{Ha}$ \\
\hline
\end{tabular}

Sumber: Miadinar, 2009; Sujatmiko, 2012

Sedangkan untuk menentukan apakah wilayah termasuk ke dalam wilayah rentan bencana kebakaran menggunakan metode pembobotan sebagai berikut:

Tabel 2. Pembobotan Wilayah Rentan Bencana

\begin{tabular}{|l|l|l|l|l|l|l|}
\hline \multirow{2}{*}{ Variabel } & \multicolumn{6}{|l}{ KLASIFIKASI } \\
\cline { 2 - 7 } & Tingkat & Bobot & Tingkat & Bobot & Tingkat & Bobot \\
\hline Kepadatan Penduduk & Rendah & 1 & Sedang & 2 & Tinggi & 3 \\
\hline Kualitas Bangunan & Rendah & 3 & Sedang & 2 & Tinggi & 1 \\
\hline Kepadatan Bangunan & Rendah & 1 & Sedang & 2 & Tinggi & 3 \\
\hline Kerapatan Jaringan Jalan & Rendah & 3 & Sedang & 2 & Tinggi & 1 \\
\hline
\end{tabular}

Sumber: Miadinar, 2009; Sujatmiko, 2012

Wilayah rentan bencana kebakaran didapatkan berdasarkan jumlah dari nilai hasil pembobotan semua variabel pada setiap unit analisis dan wilayah kejadian kebakaran permukiman dibuat berdasarkan kuantitas terjadinya kebakaran Kawasan Balubur Tamansari Kota Bandung pada setiap unit analisis.

\section{Hasil dan Pembahasan}

\subsection{Keadaan Geografi, Morphologi, dan Administrasi Kawasan Balubur Tamansari Kota Bandung}

Secara geografis, Kawasan Balubur Kota Bandung ini terletak pada Kawasan Bandung Utara dengan kondisi lahan yang mempunyai kontur lahan yang cukup berkontur dengan kemiringan mengarah ke arah Sungai Cikapundung yang membelah Kota Bandung mulai dari utara di daerah Ciumbuleuit sampai selatan di Jalan Soekarno Hatta. Kawasan Balubur ini berada di Kelurahan Lebak Siliwangi Kecamatan Coblong 
Kota Bandung. Secara administrasi Kawasan Balubur ini terdiri dari 3 RW dengan 11 RT dan mempunyai luas lahan sebesar 45 Ha. Dari segi kepemilikan lahan di kawasan ini terbagi menjadi 3 kelompok kepemilikan, yaitu (1) tanah hak milik perorangan; (2) tanah milik salah satu BUMN yaitu milik PJKA (sekarang PT. KAI); dan Tanah milik Negara yaitu marka sungai Cikapundung. Penggunaan lahan pada kawasan ini 95\% digunakan sebagai lahan terbangun, sehingga kawasan ini termasuk ke dalam salah satu kawasan padat dan kumuh (slums) penduduk dan penggunaan marka bantaran sungai (area squatters) digunakan sebagai lahan terbangun juga rumah tinggal/tempat pondokan mahasiswa (Permana, 2014).
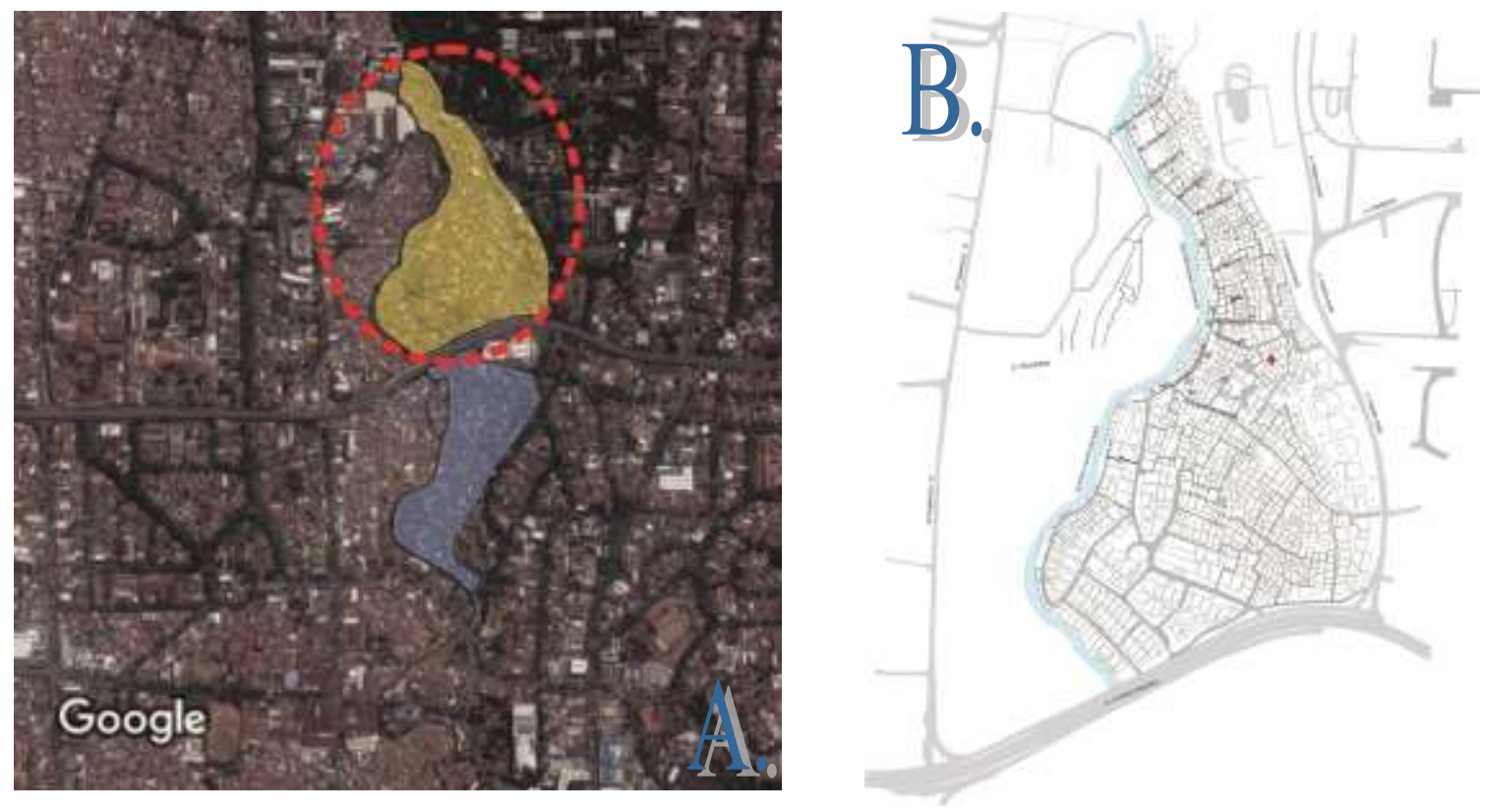

Gambar 4. A) Map Kawasan Balubur Tamansari Kota Bandung dan B) Peta Lokasi Penelitian Sumber: Google map dan Modifikasi hasil Survey tahun 2018

Secara sosial, masyarakat Balubur Tamansari terdiri dari berbagai macam latar belakang. Sebagian besar merupakan penduduk asli yang sudah mendiami lokasi tersebut sejak waktu yang cukup lama. Sedangkan sebagian lagi merupakan pendatang yang sudah memiliki rumah sendiri maupun yang menyewa rumah. Jumlah penduduk produktif yang berpendidikan SMA ke bawah berjumlah 90\% seperti dapat dilihat dalam data BPS Kota Bandung, 2011. Tingkat pendidikan yang rendah ini juga mempengaruhi kebiasaan dan pola hidup masyarakat, seperti premanisme, kriminalitas, kebiasaan sanitasi yang buruk, dan lain sebagainya. Walaupun begitu, di beberapa tempat lain masyarakat sudah ada yang giat mengikuti berbagai pelatihan maupun kegiatan swadaya dalam bidang industri rumah tangga, pengembangan potensi kawasan dalam bidang ekonomi sampai dengan pengomposan sampah. Hal ini mengindikasikan bahwa masyarakat bisa dan mau diberi pengarahan untuk dapat mengembangkan berbagai potensi di lingkungan sekitar mereka.

Pada dasawarsa terakhir ini, Kawasan Balubur Tamansari berangsur-angsur mengalami perubahan dari suatu kawasan hijau kota menjadi hunian padat penduduk yang tidak teratur dan tidak terencana. Hal ini ditunjang dengan lokasi yang strategis dan tidak adanya perencanaan dan perangkat pengendali yang mengantipasi perkembangan kawasan, mengakibatkan kawasan Balubur Tamansari mengalami penurunan kualitas fisik, lingkungan maupun sosial. Di beberapa lokasi terjadi pengalihan fungsi peruntukan lahan dari yang seharusnya berupa ruang terbuka hijau sebagai pelindung ekosistem di sepanjang sungai telah berubah tidak terkendali menjadi permukiman yang tidak teratur dan sangat padat. Secara umum, tata bangunan yang ada di sepanjang DAS Cikapundung memperlihatkan kondisi tidak terbentuknya citra kawasan jalur hijau pengaman di sepanjang sungai, bangunan tampak tidak teratur dan fungsi sungai sebagai orientasi kawasan menjadi hilang, massa bangunan yang berimpitan, berderet dan tidak memenuhi standar sempadan sungai maupun penerapan GSB tidak memenuhi kenyamanan dan persyaratan dasar kesehatan rumah. Berdasarkan data Bappeda tahun 2011, secara keseluruhan Kawasan Balubur Tamansari-Cihampelas telah mencapai tingkat kepadatan yang tinggi untuk sebuah permukiman dan didominasi oleh penyebaran perumahan liar yang melanggar ketentuan pembangunan setempat. Kondisi ini pula mengakibatkan berkurangnya area ruang terbuka publik sebagai sarana umum maupun sebagai daerah konservasi air dan hijau kota. 


\subsection{Analisis Keruangan}

\section{A. Kepadatan Penduduk}

Kepadatan penduduk merupakan jumlah banyaknya penduduk per satuan luas. Suatu wilayah disebut memiliki kepadatan penduduk tinggi bila mencapai >200 Jiwa/Ha atau kepadatan penduduk rendah apabila nilai kepadatan penduduk $<150 \mathrm{jiwa} / \mathrm{Ha}$.
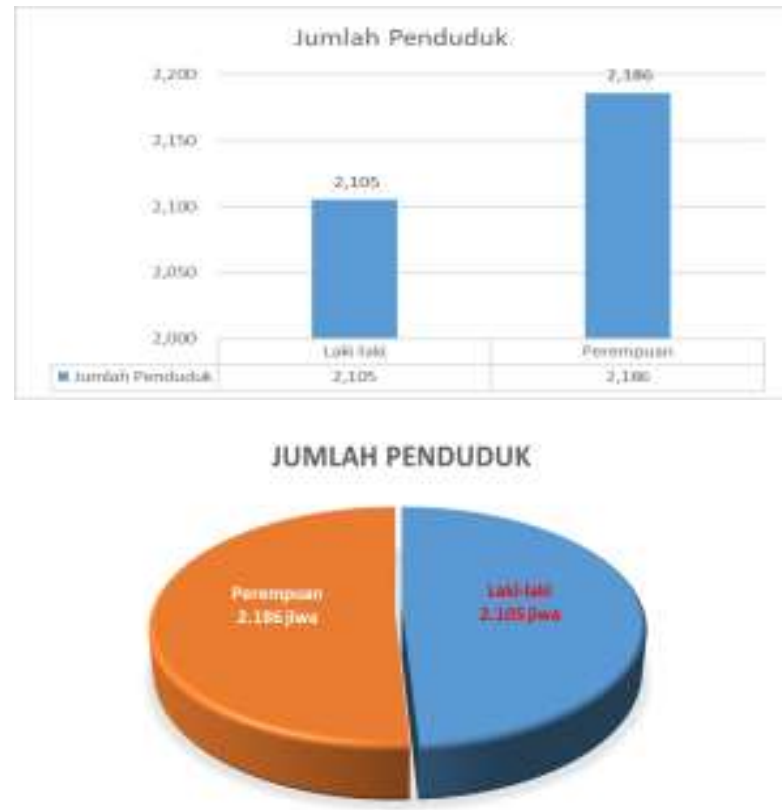

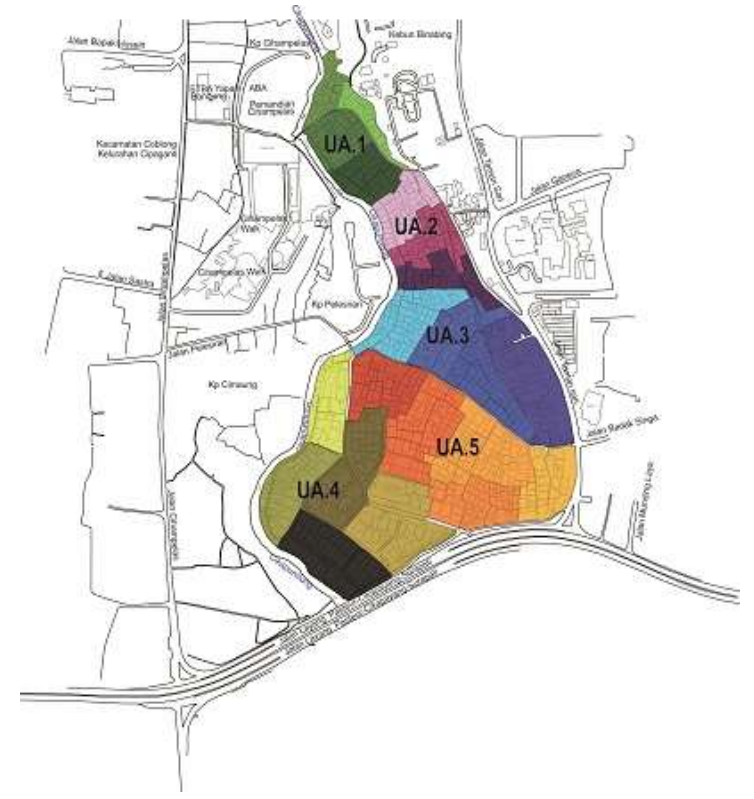

Gambar 5. A) Diagram Kepadatan Penduduk dan B) Peta pembagian wilayan Amatan (5 wilayah amatan) Sumber: Hasil analisis dan survey tahun 2018

Jumlah penduduk Kawasan Balubur Tamansari Kota Bandung adalah 4.291 jiwa dan termasuk ke dalam kawasan dengan tingkat kepadatan penduduk tinggi, yaitu >200 jiwa/Ha.

\section{B. Kualitas Bangunan}

Kualitas bangunan dalam penelitian ini merupakan perbadingan data dari bangunan permanen dan non permanen. Berdasarkan persyaratan suatu kawasan memiliki nilai kualitas bangunan yang tinggi apabila kualitas bangunan di kawasan tersebut mencapai $<5 \%$ atau kualitas bangunan rendah apabilai memiliki nilai $>15 \%$.

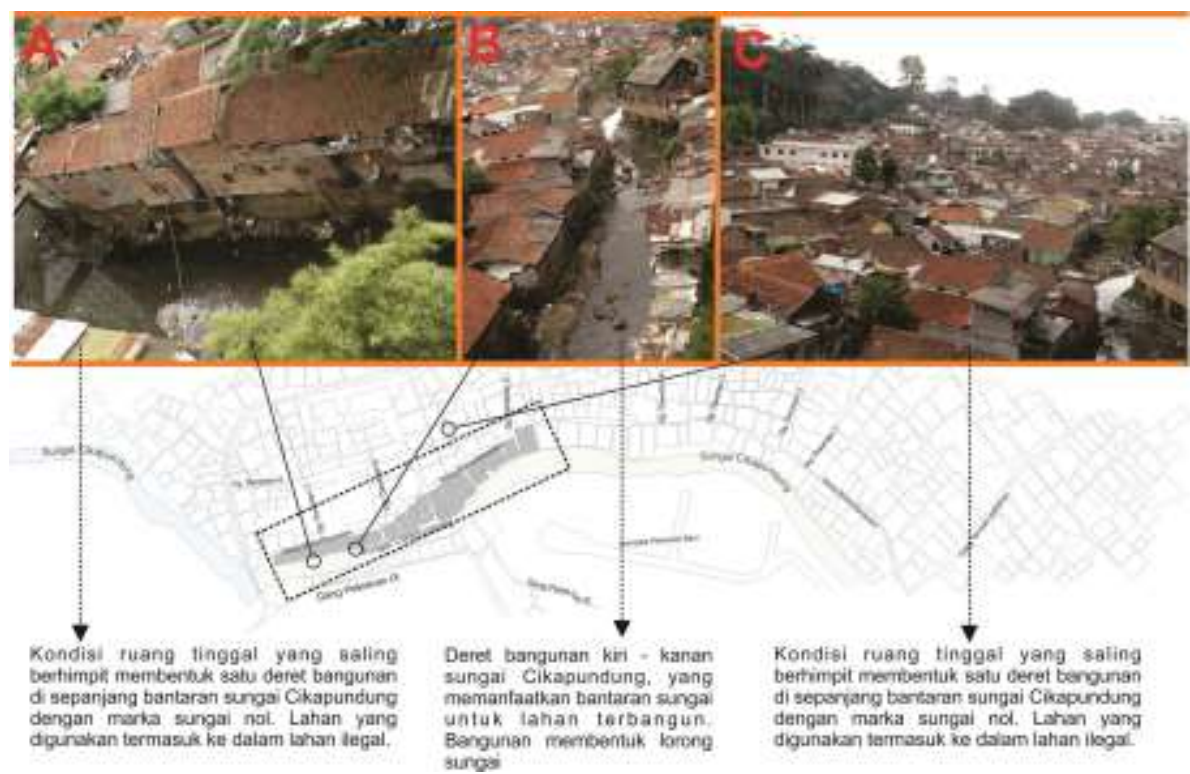

Gambar 6. Kondisi Kualitas Bangunan di Kawasan Balubur Tamansari Kota Bandung Sumber: Modifikasi hasil Survey Peneliti tahun 2011 - 2018 
Kawasan Balubur Tamansari merupakan kawasan perkampungan tidak teratur dan bangunanbangunan non-permanen, sehingga kualitas bangunan yang ada termasuk pada kualitas bangunan rendah.

\section{Kepadatan Bangunan}

Kepadatan bangunan pada penelitian ini merupakan perbandingan jumlah bangunan wilayah per satuan luas (unit/Ha). Suatu kawasan/kelurahan dikatakan memiliki kepadapat bangunan yang tinggi apabila kepadatan bangunan mencapai lebih dari 57 unit/Ha atau tingkat kepadatan bangunan yang rendah bila kepadatan bangunan kurang dari 32 unit/Ha.

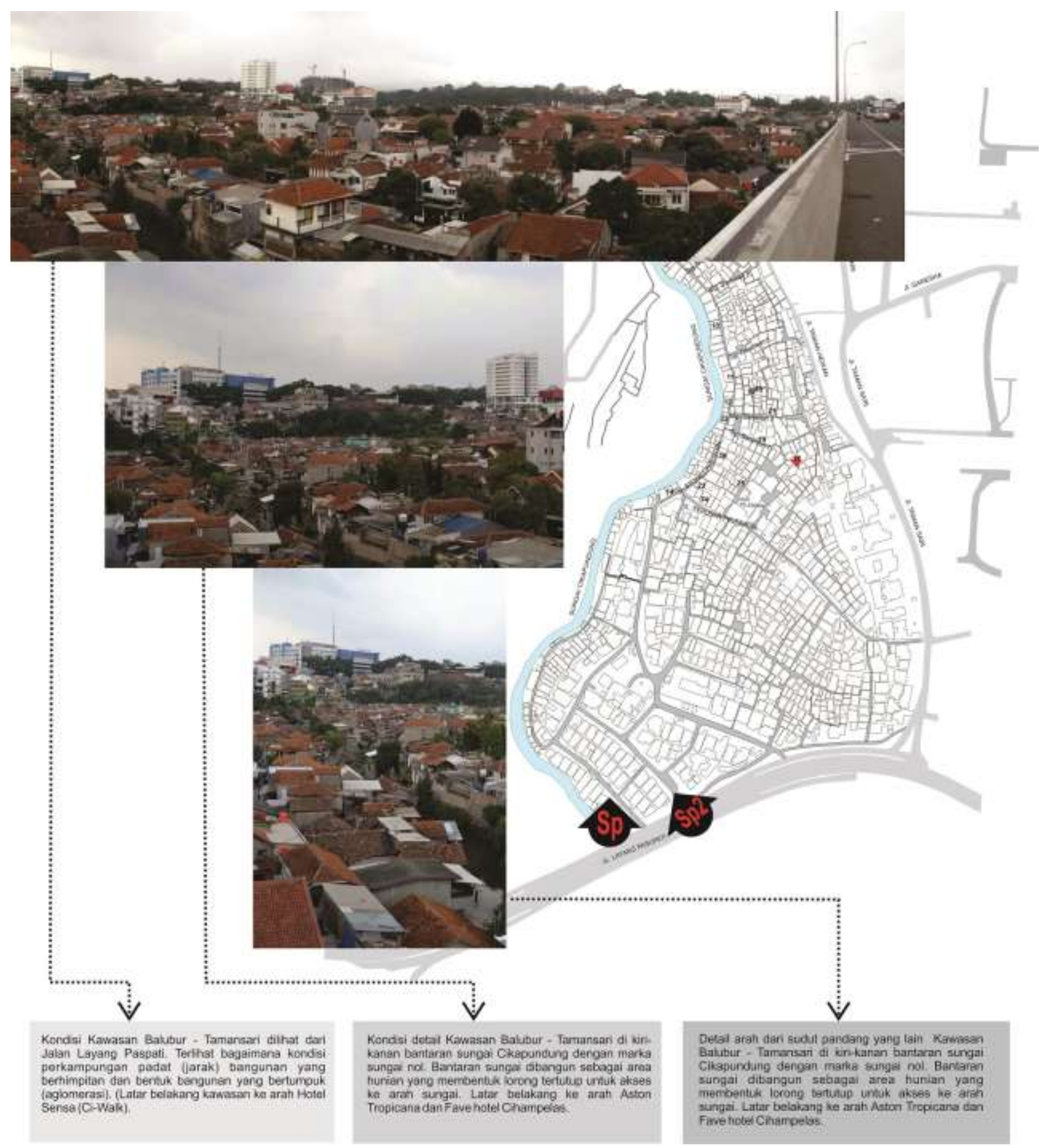

Gambar 7. Tingkat Kepadatan bangunan di Kawasan Balubur Tamansari Sumber: Modifikasi hasil Survey Peneliti tahun 2011 - 2018 unit/Ha.

Berdasarkan hasil amatan kawasan Balubur Tamansari memiliki kepadatan bangunan yang tinggi >57 


\section{Tingkat Kerapatan jaringan Jalan}

Kerapatan jaringan jalan merupakan jumlah panjang jalan. Kerapatan jaringan jalan pada penelitian ini merupakan perbandingan jumlah panjang jaringan jalan per satuan luas $(\mathrm{m} / \mathrm{Ha})$. Suatu kawasan dikatakan memiliki kerapatan jaringan jalan yang tinggi apabila kerapatan jaringan jalan mencapai lebih dari $10 \mathrm{~m} / \mathrm{Ha}$ dan kerapatan jaringan jalan rendah apabila kerapatan jaringan jalan kurang dari $75 \mathrm{~m} / \mathrm{Ha}$.
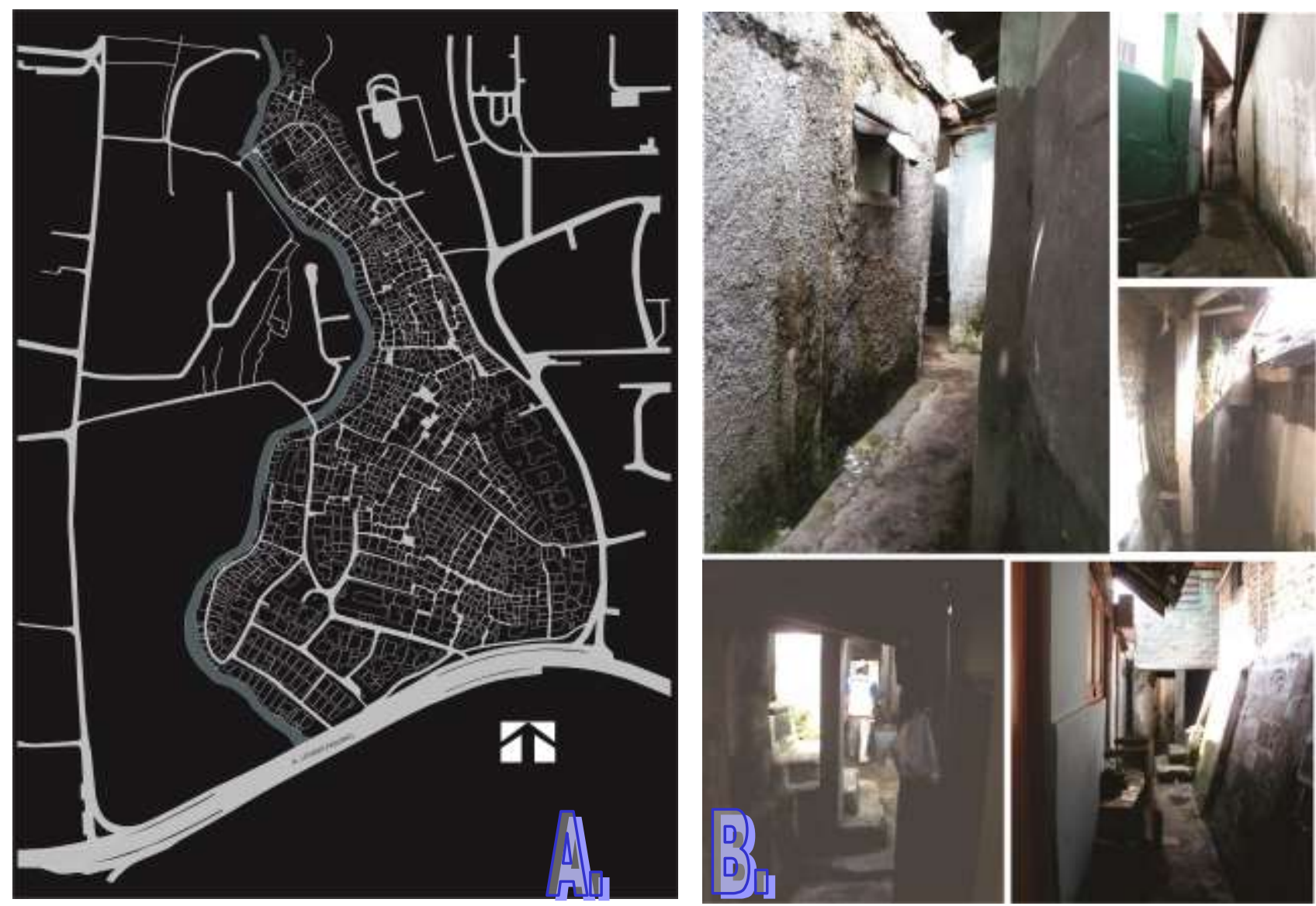

Gambar 8. A) Pola kerapatan jaringan jalan di Kawasan Balubur Tamansari;

B) Suasana Jalan/Gang di Kawasan Balubur Tamansari

Sumber: Modifikasi hasil Survey Peneliti tahun 2011 - 2018

Berdasarkan klasifikasi kerapatan jaringan jalan termasuk kedalam kerapatan jaringan yang rendah karena jenis jaringan jalan yang banyak ditemui sebagian besar adalah jalan lingkungan atau bahkan hanya sebagai gang dengan lebar jalan/gang antara $0,8-1,6 \mathrm{~m}$.

\subsection{Analisis Risiko Kebakaran}

\section{A. Bahaya $($ Hazard/H)}

Bahaya kebakaran di kawasan Balubur Tamansari Kota Bandung dipengaruhi oleh kondisi eksisting guna lahan dan kepadatan bangunan. Klasifikasi tingkat bahaya kebakaran guna lahan didasarkan pada angka klasifikasi risiko bahaya kebakaran berdasarkan Permen PU nomor 20 tahun 2009 tentang Pedoman Teknis Manajemen Penanggulangan Kebakaran di Perkotaan (Sahputra, Sutikno, \& Sandhyavitri, 2017).

Berdasarkan parameter guna lahan dengan obyek kajian pada $3 \mathrm{RW}$ dan $11 \mathrm{RT}$, maka Kawasan Balubur Tamansari termasuk ke dalam kawasan bahaya yang tinggi. Hal ini karena peruntukan lahan mayoritas adalah pemukiman dengan angka klasifikasi risiko bahaya kebakaran tinggi (nilai skor 3). Pada penilaian parameter kepadatan bangunan, Kawasan ini termasuk ke dalam tingkat kepadatan bangunan tinggi (>57 unit/Ha). Dengan demikian overlay parameter guna lahan dan kepadatan bangunan menghasilkan bahaya kebakaran tinggi. 


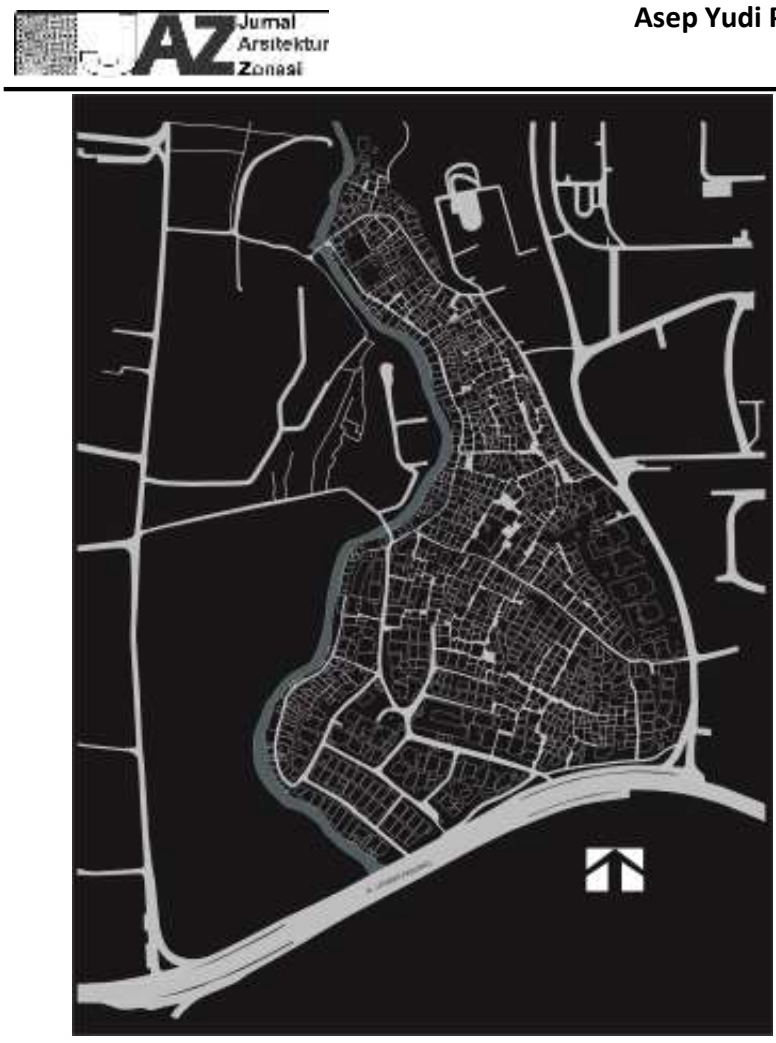

Gambar 9. A) Jaringan Jalan/gang Kawasan Balubur Tamansari dan B) Masa Bangunan Kawasan Balubur Tamansari Kota Bandung

Sumber: Modifikasi hasil Survey Peneliti tahun 2011 - 2018

\section{B. Kerentanan (Vulnerability /V)}

Analisis kerentanan merupakan hasil dari overlay antara kerentanan sosial dengan fisik. Kerentanan sosialdidapatkan dari kepadatan penduduk dan kerentanan fisik didapat dari ketersediatan fasilitas pemadam kebakaran dan lebar jalan. Kerentanan sosial didapatkan dari kepadatan penduduk. Untuk ketersediaan fasilitas pemadam kebakaran termasuk ke dalam kategori sedang. Hal ini karena minimnya fasilitas peralatan pebakaran dan terhalangnya sumber air (sungai) akibat dari marka sungai yang dibangun, walaupun pada beberapa titik masih dibuka untuk jalur evakuasi.

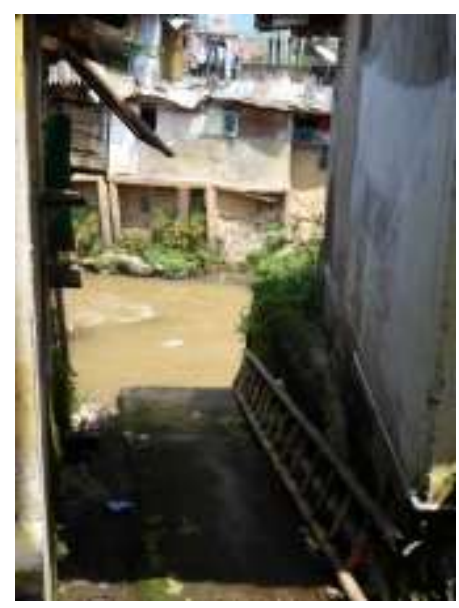

Gambar 10. Jalur Evakuasi Lingkungan dengan Akses Langsung ke Sungai Cikapundung

Sumber: Hasil survey Penelitian tahun 2011-2018

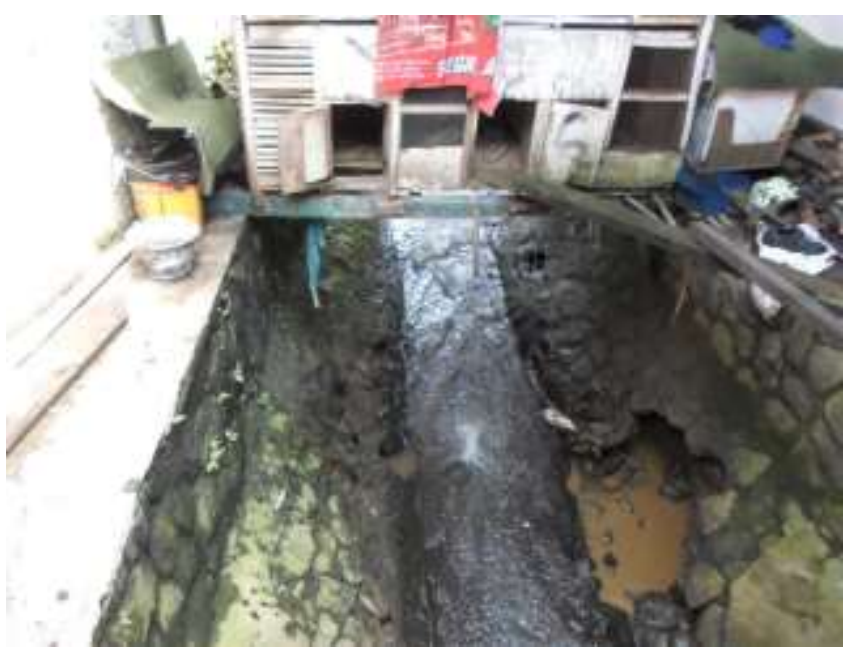

Gambar 11. Penyalahgunaan Jalur Evaluasi Lingkungan dengan Akses Langsung ke Sungai Cikapundung dengan Membangun Kandang Ayam di Atas Jalur Evakuasi

Sumber: Hasil survey Penelitian tahun 2011-2018

Kawasan Balubur Tamansari tumbuh dan berkembang menjadi kawasan padat penduduk, hal ini seiring dengan perkembangan Kota Bandung. Kawasan ini tumbuh menjadi kampung padat sebagai bentuk dari kebutuhan hunian para migran mahasiswa, akibat tumbuh dan berkembang beberapa perguruan tinggi yang berada di sekitar Kawasan Balubur Tamansari. Terdapat jalur evakuasi alat pemadam kebakaran, pada 
Gang Daranten sebagai gang utama terdapat akses langsung menuju sungai di mana ruang ini harus steril dari bangunan. Oleh karena itu ketika terjadi kebakaran, alat yang tersedia pompa maupun selang bisa langsung digunakan. Peralatan untuk menanggulangi bahaya kebakaran disimpan di setiap Pos RT masingmasing yang letaknya tidak jauh dari gang yang menuju langsung ke sungai.

Lebar jalan/gang antara 0,8 - 1,6 meter menyulitkan akan proses evakuasi terutama dengan mobil pemadam kebakaran dalam mencapai titik kebakaran. Kondisi kawasan Balubur Tamansari merupakan kampung kota dengan aksesibilitas jalan sempit. Klasifikasi jalan dengan lebar jalan seperti ini termasuk ke dalam tingkat kerentanan sedang pada jalur jalan/gang Terusan Taman Hewan dan Terusan Pelesiran/Jln. Stone (lebar $=2,5$ meter) dan tingkat kerentanan tinggi pada semua gang dengan lebar antara 0,80 - 1,6 meter yaitu mulai dari Gang Daranten 1 - 7.

\section{Kapasitas (Capacity/C)}

Parameter kapasitas masyarakat dalam menghadapi bahaya kebakaran menggunakan parameter dari Perka BNPB nomor 2 tahun 2012 (Handoko, Nugraha, dan Prasetyo, 2017) tentang Pedoman Umum Pengkajian risiko bencana, pendidikan bencana, pengurangan faktor risiko dasar serta pembangunan kesiapsiagaan. Untuk menjaring hasil dari parameter kapasitas ini digunakan kuesioner yang disampaikan kepada 150 responden. Hasilnya menunjukkan tingkat pengetahuan masyarakat Kawasan Balubur Tamansari berada di tingkat sedang, masyarakat sudah memiliki cukup pengetahuan mengenai penanganan kebakaran. Fasilitas pemadam kebakaran, sosialisasi dan program terkait penanganan kebakaran sudah dilakukan oleh aparat RW dan RT.

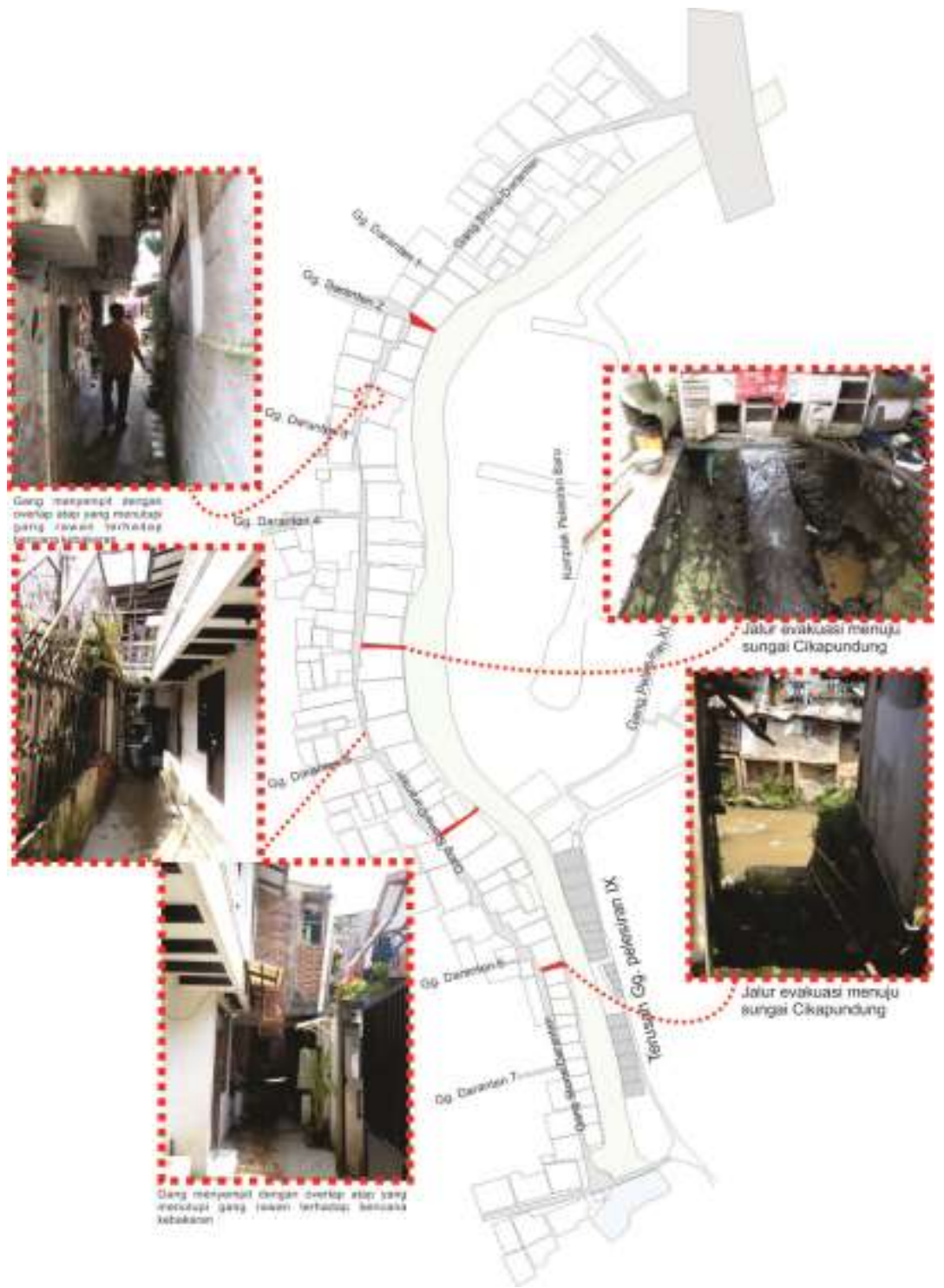

Gambar 12. Jalur Evakuasi Lingkungan dengan Akses Langsung ke Sungai Cikapundung Sumber: Hasil survey Penelitian tahun 2011-2012 


\subsection{Risiko Bencana Kebakaran}

Tingkat risiko Bencana kebakaran merupakan hasil dari overlay bahaya-kerentanan, dan kemudian dioverlay lagi dengan tingkat kapasitas masyarakat Kawasan Balubur Tamansari Kota Bandung. Berdasarkan analisis risiko bencana di Kawasan Balubur Tamansari termasuk ke dalam tingkat risiko tinggi terhadap kebakaran.

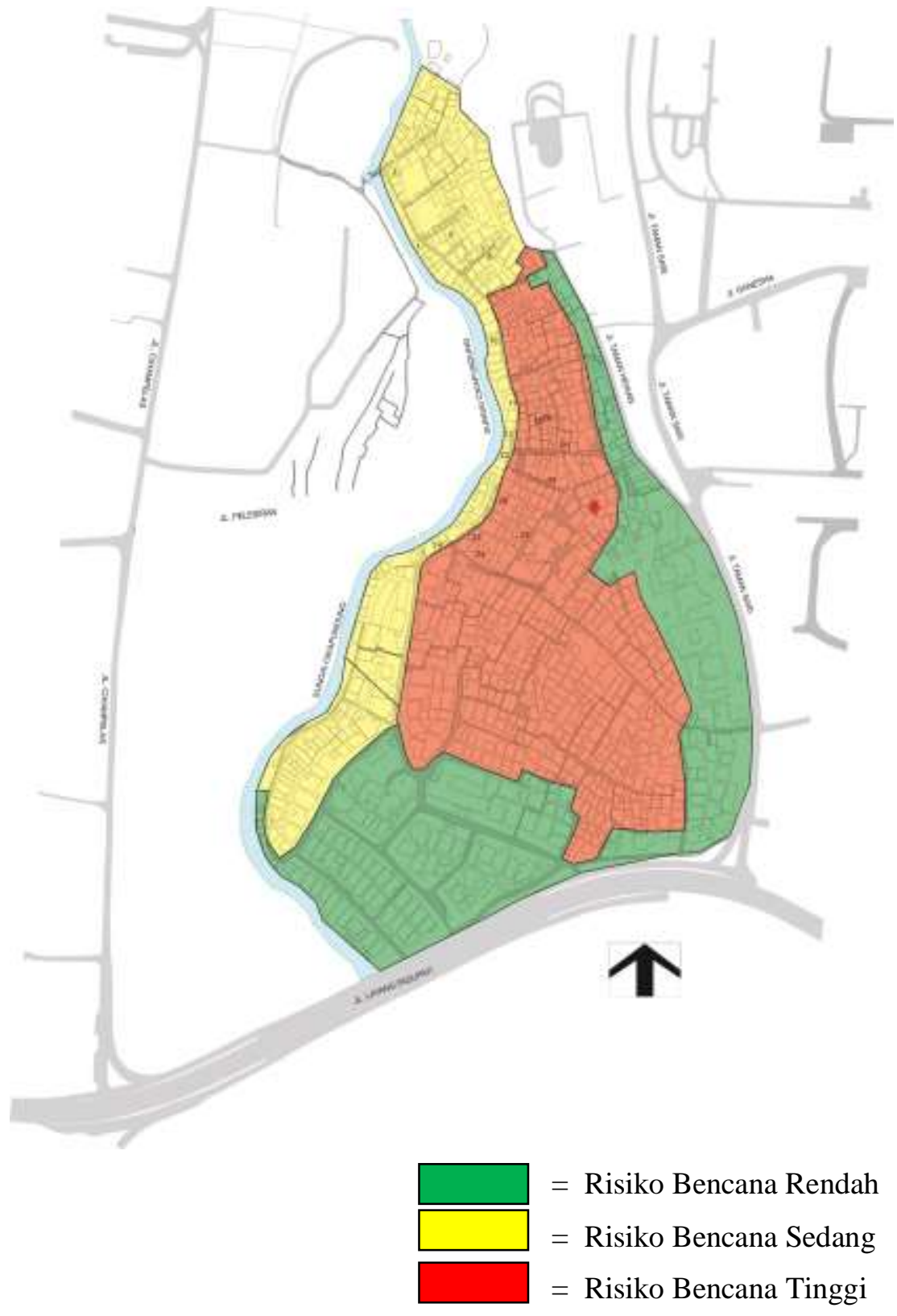

Gambar 13. Tingkat Risiko Bencana Kebakaran

Sumber: Hasil analisis peneliti, 2018

Berdasarkan hasil analisis risiko bencana kebakaran di Kawasan Balubur Tamansari dibagi ke dalam 3 kategori, yaitu (a) kategori rendah meliputi daerah terusan pelesiran dengan lebar jalan/gang 2,5 meter, pola kerapatan bangunan cenderung tertata; (b) kategori sedang meliputi daerah sekitar jalan stone/ Daranten dengan lebar jalan/gang 1,6 meter, pola tata bangunan organik mengikuti sepanjang sungai Cikapundung; dan (c) kategori tinggi merupakan daerah yang dikelilingi oleh daerah/zone rendah dan sedang dengan lebar gang $0,8-1,2$ meter dan tingkat kepadatan bangungan tinggi.

\section{Kesimpulan}

Berdasarkan hasil analisis keruangan dan risiko kebakaran pada Kawasan Balubur Tamansari Kota Bandung, maka kawasan ni memiliki tingkat risiko kebakaran tinggi. Hal ini disebabkan bahaya dan kerentanan mayoritas berada ditingkat tinggi dan ditunjang dengan minimnya tingkat kapasitas masyarakat yang terkait denga penanggulangan dan kersiapsiagaan dalam menghadapi kebakaran. 
Kawasan Balubur Tamansari tumbuh dan berkembang menjadi kawasan padat penduduk, hal ini seiring dengan perkembangan Kota Bandung. Kawasan ini tumbuh menjadi kampung padat sebagai bentuk dari kebutuhan hunian para migran mahasiswa, akibat tumbuh dan berkembang beberapa perguruan tinggi yang berada di sekitar Kawasan Balubur Tamansari. Terdapat jalur evakuasi alat pemadam kebakaran, pada Gang Daranten sebagai gang utama terdapat akses langsung menuju sungai di mana ruang ini harus steril dari bangunan. Oleh karena itu ketika terjadi kebakaran, alat yang tersedia pompa maupun selang bisa langsung digunakan. Peralatan untuk menanggulangi bahaya kebakaran disimpan di setiap Pos RT masingmasing yang letaknya tidak jauh dari gang yang menuju langsung ke sungai.

\section{Ucapan Terima Kasih}

Pada kesempatan ini penulis memberikan penghargaan Universitas Pendidikan Indonesia yang telah memberikan dana melalui program pengembangan dosen dan kepada aparat dan masyarakat di Kawasan Balubur Tamansari khususnya warga Taman Hewan Kota Bandung yang bersedia untuk memberikan informasi dan respon dalam pelaksanan penelitian ini.

\section{Referensi}

Badan Pusat Statistik Kota Bandung. (2018). Kota Bandung Dalam Angka 2018. Bandung: Badan Pusat Statistik Kota Bandung.

BPS Kota Bandung. (2017). Data Statistik Kota Bandung tahun 2017. Bandung: Badan Pusat Statistik Kota Bandung.

Budihardjo, E. (1984). Sejumlah Masalah Permukiman Kota. Bandung: Alumni.

Budihardjo, E. (1997). Tata Ruang Perkotaan. Bandung: Alumni.

Budihardjo, E. (2011). PENATAAN RUANG PEMBANGUNAN PERKOTAAN (I). Bandung: ALUMNI, PT.

Handoko, D., Nugraha, A. L., dan Prasetyo, Y. (2017). Kajian Pemetaan Kerentanan Kota Semarang terhadap Multi Bencana Berbasis Pengindraan Jauh dan Sistem Informasi Geografis. Jurnal Geodesi Undip, 4(3), 1-10. Retrieved from https://ejournal3.undip.ac.id/index.php/geodesi/article/view/17173

Januandari, M. U., Rachmawati, T. A., dan Sufianto, H. (2017). Analisa Risiko Bencana Kebakaran Kawasan Segitiga Tunjungan Surabaya, 5(2), 149-158. https://doi.org/10.14710/jpk.5.2.

Kunto, H. (1984). Bandung Tempo Doele. Bandung: PT. Granesia.

Kunto, H. (1986a). Balai Agung di Kota Bandung. Bandung: PT. Granesia.

Kunto, H. (1986b). Semerbak Bunga di Bandung Raya. Bandung: PT. Granesia.

Marfai, M. A., Cahyadi, A., dan Anggraini, D. F. (2013). Tipologi, Dinamika, dan Potensi Bencana Di Pesisir Kawasan Karst Kabupaten Gunungkidul. Forum Geografi, 27(2), 147-158.

Miadinar, A. (2009). Wilayah Rawan Kebakaran di Kota Yogyakarta tahun 2008. Universitas Indonesia.

Nurwulandari, F. S. (2012). Kajian Kemampuan Masyarakat di Permukiman Padat dalam Mitigasi Kebakaran (Studi Kasus: Kelurahan Tamansari Kota Bandung). Institut Teknologi Bandung.

Nurwulandari, F. S. (2016). Kajian Mitigasi Bencana Kebakaran di Pemukiman Padat. Jurnal Informasi,Manajemen Dan Teknologi, 18(1).

Permana, A. Y. (2011). Penerapan Konsep Perancangan Smart Village sebagai Local Genius Arsitektur Nusantara. Jurnal Arsitektur Komposisi, 9(1), 24-33.

Permana, A. Y. (2012a). Eco-architecture Sebagai Konsep Urban Development di Kawasan Slums dan Squatters Kota Bandung (pp. 1-11). Semarang.

Permana, A. Y. (2012b). Peran Ruang Terbuka Publik di Kawasan Slums dan Squatters sebagai "Ruang Ketiga" (Kasus: Kawasan Bantaran Sungai Cikapundung di Kota Bandung. In SEMINAR NASIONAL "Sustainable Urbanism" Adaptasi Perubahan Ruang Perkotaan-Pendekatan Teoritik dan Praktek (pp. 84-98). Semarang: Media Plano : Biro Penerbit Planologi UNDIP.

Permana, A. Y. (2014). Transformasi Gubahan Ruang: Pondokan Mahasiswa di Kawasan Balubur Tamansari Kota Bandung. Universitas Diponegoro. Retrieved from http://eprints.undip.ac.id/62084/

Permana, A. Y., Soetomo, S., Hardiman, G., dan Buchori, I. (2013). Smart Architecture as a Concept of Sustainable Development in the Improvement of the Slum Settlementarea in Bandung. Internasional Refereed Journal of Engineering and Science, 2(9), 26-35.

Permana, A. Y., Sumarna, N., dan Wijaya, K. (2017). Membangun Kampung Kreatif melalui Kolaborasi Mahasiswa dengan Masyarakat. Kasus: Kawasan Balubur-Tamansari Kota Bandung. In Prosiding Seminar Nasional "Perencanaan Pembangunan Inklusif Desa-Kota" (pp. 51-58). Padang: Asosiasi Sekolah Perencanaan Indonesia (ASPI), Perhimpunan Ekonomi Pertanian Indonesia (PERHEPPI), dan Program Pascasarjana Universitas Andalas. 
Permana, A. Y., Susanti, I., dan Wijaya, K. (2018). The Transformation of Gegerkalong Girang Area, Bandung City: amid Educative and Religious Areas. IOP Conference Series: Earth and Environmental Science, 213(1), 012022. https://doi.org/10.1088/1755-1315/213/1/012022

Permana, A. Y., dan Wijaya, K. (2013). Education City As Identity of Bandung City. In International Conference on Urban Heritage and Sustainable Infrastrcture Development (UHSID) (pp. 15-19). Semarang: Architecture Departement of Diponegoro University.

Permana, A. Y., dan Wijaya, K. (2018). Spatial change transformation of educational areas in Bandung. In IOP Conference Series: Earth and Environmental Science (Vol. 99). https://doi.org/10.1088/17551315/99/1/012029

Rahmat, A., Prianto, E., dan Sasongko, S. B. (2018). Studi Evaluasi Model Bentuk Atap Dan Fenomena. Jurnal Arsitektur Zonasi, 1(2), 112-122. https://doi.org/http://10.17509/jaz.v1i2.13560

Sahputra, R., Sutikno, S., dan Sandhyavitri, A. (2017). Mitigasi Bencana Kebakaran Lahan Gambut Berdasarkan Metode Network Analysis Berbasis GIS (Studi Kasus: Pulau Bengkalis). Jurnal Online Mahasiswa Fakultas Teknik Universitas Riau, 4(2), 1-6. Retrieved from https://jom.unri.ac.id/index.php/JOMFTEKNIK/article/view/15391

Soetomo, S. (2012). Urbanisasi dan Morfologi: Proses perkembangan peradaban dan wadah ruang fisiknya: Menuju Ruang Kehidupan yang Manusiawi. Yogyakarta: Graha Ilmu.

Sujatmiko, R. (2012). Kejadian Kebakaran Permukiman Kota Bekasi Tahun 2010. Universitas Indonesia.

Sukmo, R., Suroto, dan Wahyuni, I. (2016). Analisis Implementasi Sistem Tanggap Darurat Kebakaran Di Kawasan Pemukiman Padat Penduduk Kotamadya Jakarta Timur (studi Kasus di RW 016 Kelurahan Kayu Putih, Kecamatan Pulogadung, Kotamadya Jakarta Timur). Jurnal Kesehatan Masyarakat FKM Universitas DIponegoro, 4(3), 591-602.

Taridala, S., Yudono, A., Ramli, M. I., dan Akil, A. (2017). Model Penilaian Risiko Kebakaran Perkotaan dengan Sistem Pakar Berbasis Gis Grid-Based. Jurnal Majalah Geografi Indonesia, 31(2), 97-106.

Voskuil, R. P. G. A. (2007). Bandung Citra Sebuah Kota. Bandung: Departemen Planologi ITB bekerja sama dengan PT. Jagaddhita.

Widjaja, P. (2013). Kampung - Kota Bandung (Pertama). Yogyakarta: Graha Ilmu.

Wijaya, K., Permana, A. Y., dan Swanto, N. (2017). Kawasan Bantaran Sungai Cikapundung Sebagai Pemukiman Masyarakat Berpenghasilan Rendah (MBR) Di Kota Bandung. ARCADE, 1(2), 57-68. 